\title{
Bacterioplankton production in the nearshore zone during upwelling off central Chile
}

\author{
George B. McManus ${ }^{1}$, William T. Peterson ${ }^{2, *}$ \\ ${ }^{1}$ Institute of Ecosystem Studies, New York Botanical Garden, Box AB, Millbrook, New York 12545, USA \\ ${ }^{2}$ Marine Sciences Research Center, SUNY Stony Brook, New York 11794, USA
}

\begin{abstract}
We measured bacterioplankton abundance and productivity during 3 upwelling cycles at a nearshore station off central Chile $\left(36^{\circ} 30^{\prime} \mathrm{S}\right.$ ) in January 1986 . Standing stock ( 43 to $113 \times 10^{12} \mathrm{cells} \mathrm{m}^{-2}$ over the $25 \mathrm{~m}$ water column) and productivity were lowest during periods of active upwelling and highest during periods of calm or light winds and water column stratification. Bacterial productivity peaked 1 to $2 \mathrm{~d}$ after primary productivity and varied by about an order of magnitude $(0.13$ to $1.40 \mu \mathrm{gC}$ $\mathrm{l}^{-1} \mathrm{~h}^{-1}$ ) between newly upwelled and stratified waters. Surface primary productivity was much more variable (50-fold variation) and thus appeared to respond more strongly to the hydrographic events of the upwelling cycle. Net bacterial production was often a substantial fraction of primary production (up to about $50 \%$ ), especially in newly upwelled water The abundance of heterotrophic microflagellates also varied in response to the upwelling cycle, with maximum abundances occurring during periods of stratification. The duration of stratified conditions between successive upwelling events may determine how much bacterial production is mineralized by grazers in the nearshore zone and how much is subsequently transported offshore.
\end{abstract}

\section{INTRODUCTION}

Much of our knowledge about the food webs of coastal upwelling ecosystems has come from multidisciplinary oceanographic studies performed during the 1970 s off the coasts of Oregon, Northwest Africa, and Peru (reviewed in Richards 1981). Most of this work pre-dates the emergence of the 'new paradigm' in biological oceanography which ascribes greater importance to the bacteria and nanoplankton in the food web (Pomeroy 1974). Bacterioplankton in upwelling systems was considered to be unimportant in the transfer of material to higher trophic levels (Smith et al. 1977), and primary production was thought to be utilized in a short, efficient food chain dominated by large phytoplankton and herbivorous copepods and fish (Ryther 1969, Ryther et al. 1971). As a result, information on the abundance and productivity of bacterioplankton in coastal upwelling ecosystems is limited.

The introduction of new methods, especially the use of epifluorescence microscopy and radio-labelled organic substrates for the measurement of bacterial

\footnotetext{
- Present address: Zoology Department, University of Cape Town, Rondebosch 7700 , South Africa
}

abundance and activity, has led to a greater appreciation of the importance of bacterioplankton in the utilization of primary production in coastal waters. It has been estimated that 10 to $50 \%$ of primary production passes through the bacterioplankton (Andrews \& Williams 1971, Sieburth et al. 1977, Hagström et al. 1979, Fuhrman \& Azam 1982) and that bacteria are dividing about 0.2 to $2 \mathrm{~d}^{-1}$ (van Es \& Meyer-Reil 1982, Ducklow 1983). Recent work in coastal upwelling ecosystems has shown that bacterial abundance is similar to that in other coastal environments and that it varies in response to the upwelling cycle (Field et al. 1980, Zimmermann et al. 1980, Gocke et al. 1983 , Rheinheimer \& Schmaljohann 1983, Hanson et al. 1986).

As part of a larger study whose goal was to describe the relationship between the hydrographic events of the upwelling cycle and primary and secondary production of the plankton, we obtained a $21 \mathrm{~d}$ time series of bacterial abundance and production, and heterotrophic microflagellate abundance, at a nearshore station off central Chile. This paper reports the results of those observations, and discusses the importance of bacterial production in the nearshore zone during coastal upwelling. 


\section{MATERIALS AND METHODS}

Study site. The station was located approximately $1 \mathrm{~km}$ offshore of the tip of the Coliumo Peninsula, Chile $\left(36^{\circ} 30^{\circ} \mathrm{S}, 72^{\circ} 58^{\prime} \mathrm{W}\right)$ in $25 \mathrm{~m}$ of water. During the austral summer in this area variations in local winds with periods of 2 to $7 \mathrm{~d}$ cause cold $\left(<13{ }^{\circ} \mathrm{C}\right)$, nutrient-rich water $\left(25 \mu \mathrm{MNO}_{3}\right)$ to be brought to the surface. Nearshore blooms of phytoplankton occur in this water during periods when southerly winds become calm or reverse (Arcos \& Wilson 1984).

The station was visited 19 times from 6 to 27 January 1986. Samples for bacterial abundance were taken from depths of $0,5,10,15$ and $23 \mathrm{~m}$ (except on 6 and 8 Jan, when only surface samples were taken). Twenty $\mathrm{ml}$ of water from each depth was preserved with filtered, unbuffered glutaraldehyde $(1 \%$ final concentration) and stored on ice in the dark. Slides for bacterial counts were prepared within a few hours of collection using the fluorochrome acridine orange, according to the method of Hobbie et al. (1977). Ten $\mathrm{ml}$ subsamples from the surface water were filtered 10.8 $\mu \mathrm{m}$ pore-size Nuclepore filters) and stained with the fluorochrome proflavine for enumeration of protozoa (Haas 1982). These preparations were stored frozen for up to 3 wk until they could be counted.

Samples for measurement of bacterial production were taken from the surface with a plastic bucket, and from $15 \mathrm{~m}$ with a PVC Niskin bottle. Duplicate $20 \mathrm{ml}$ subsamples were placed in sterile whirlpak bags, inoculated with methyl- ${ }^{3} \mathrm{H}$ thymidine $(5 \mathrm{~nm}$ final concentration) and incubated for 25 to $45 \mathrm{~min}$ in a bucket filled with surface seawater to prevent excessive heating. The surface samples experienced full sunlight; those from $15 \mathrm{~m}$ were covered with several layers of neutral density screen, although no attempt was made to simulate the in situ light field exactly. A killed control $(0.1 \%$ glutaraldehyde) was used to check for growth of bacteria in the thymidine stock and for adsorption of label onto the filters used to collect the samples at the end of the incubations. Material insoluble in $5 \%$ cold trichloroactetic acid was collected on $0.45 \mu \mathrm{m}$ pore-size Millipore filters and assayed by liquid scintillation spectroscopy. A conversion factor of $2 \times 10^{18}$ cells per mole thymidine incorporated was used to compute bacterial production (Fuhrman \& Azam 1982). Bacterial carbon was estimated as $20 \mathrm{fgC}$ cell ${ }^{-1}$ (Lee \& Fuhrman 1987).

Primary productivity was measured using the ${ }^{14} \mathrm{C}$ technique (Parsons et al. 1984) on $300 \mathrm{ml}$ samples comprised of equal volumes of water pooled from collections made at 1,3 , and $5 \mathrm{~m}$ with a small pump equipped with a plastic impeller and a $1.5 \mathrm{~cm}$ diameter plastic hose. They were incubated in full sunlight in a container with running surface seawater.
Temperature was measured with reversing thermometers. A more comprehensive description of hydrographic, chemical, and biological measurements made during the study will be presented elsewhere (Peterson et al. in press).

\section{RESULTS}

Three upwelling events occurred during our study, when equatorward winds blew consistently for several days (Fig. 1), causing cold, nutrient-rich water to appear at the surface. After a lag of about $1 \mathrm{~d}$ from the onset of the wind, the water column was well-mixed (Fig. 2a). Calm or northerly winds resulted in a stratified water column. There were 3 periods of

WIND STRESS

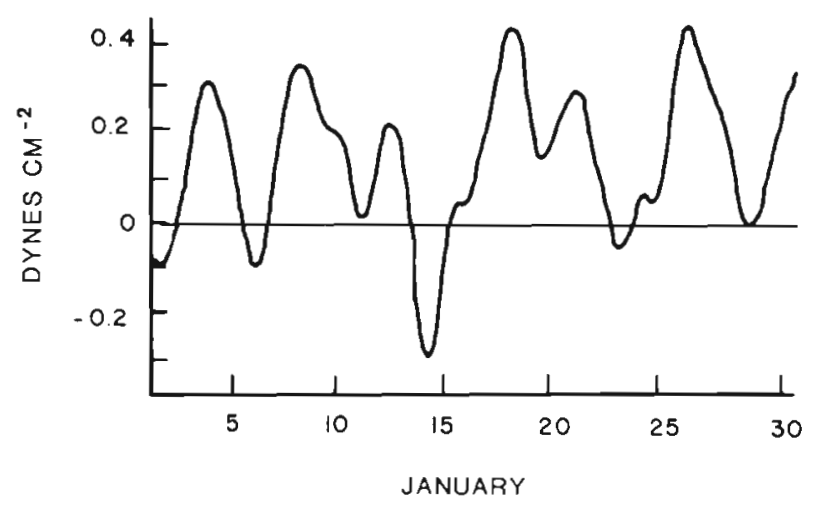

Fig. 1. Longshore component of the wind stress during January 1986, calculated from wind velocities measured with a Beckman anemometer at Carriel Sur Airport, approximately $40 \mathrm{~km}$ south of the study site. Measurements $\left(0.6 \mathrm{~min}^{-1}\right)$ were averaged over 10 min intervals and converted into hourly means for the graph. Equatorward winds (upwelling-favorable) are positive

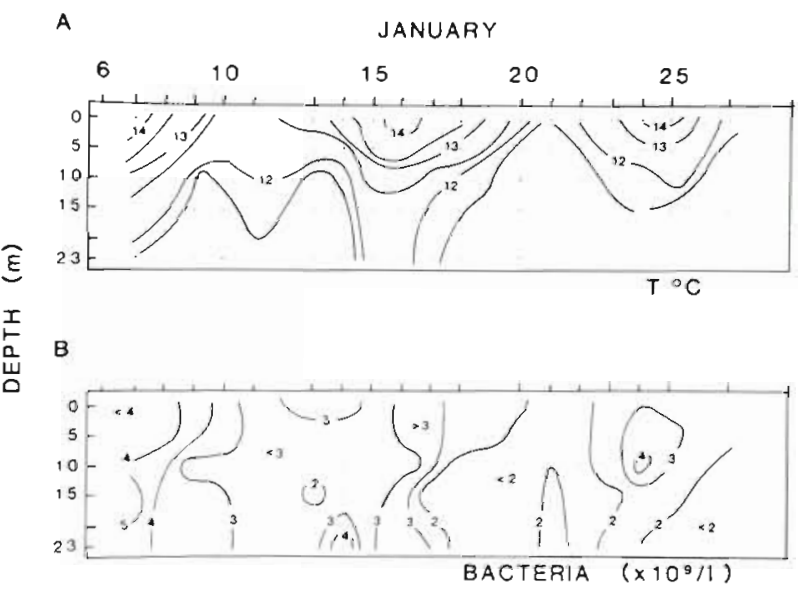

Fig. 2. Contours of (A) temperature and (B) bacterial abundance with time and depth. Sample depths are marked by dots 


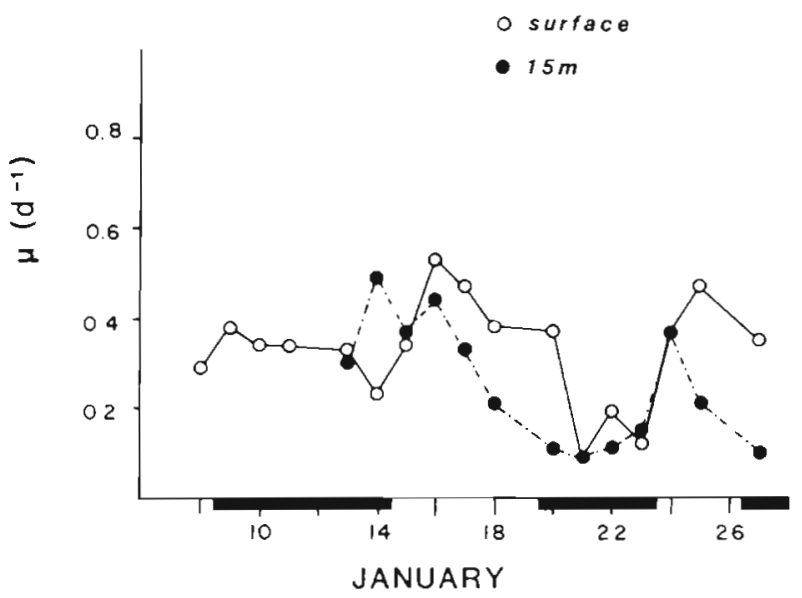

Fig. 3. Per capita growth rates of bacteria (thymidine-measured productivity divided by abundance) at the surface and 15 $\mathrm{m}$. Black bars on the horizontal axis indicate periods of active upwelling, defined as dates on which the surface-to-bottom density gradient $(\Delta$ sigma- $t / \Delta z)$ exceeded 0.015

stratification (beginning of the study until $8 \mathrm{Jan}$; 15 to $19 \mathrm{Jan} ;$ and 24 to $26 \mathrm{Jan}$ ) and 3 periods when the water column was well-mixed (9 to $14 ; 20$ to 23; and $27 \mathrm{Jan}$, the last day of sampling for bacteria). Periods of stratification were associated with higher bacterial biomass (Fig. 2b) and chlorophyll (Peterson et al. in press).

Bacterial specific growth rates were highest during stratification and lowest during active upwelling (Fig. 3). Peaks in the growth rate at $15 \mathrm{~m}$ occurred 1 to $2 \mathrm{~d}$ ahead of those at the surface, and the decline in growth associated with the onset of upwelling also occurred earlier in the deeper samples.

Bacterial productivity in the surface samples showed a temporal pattern similar to that of the phytoplankton, except during the first period of active upwelling ( 9 to $14 \mathrm{Jan}$ ), when bacterial productivity remained high (Fig. 4a). Both bacterial and phytoplankton productivity declined sharply during the second period of upwelling ( 20 to $23 \mathrm{Jan}$ ). This seemed to be a rather stronger event than the first, with bacterial abundances of less than $2 \times 10^{9}$ cells $~^{-1}$ occurring at all depths, and Secchi depths exceeding $15 \mathrm{~m}$. As a percentage of primary productivity, bacterial productivity was highest during active upwelling and lowest during periods of stratification (Fig. 4b), because primary productivity values varied 50 -fold between events whereas bacterial productivity ranged over only one order of magnitude.

Heterotrophic microflagellates, like bacterioplankton, occurred in greater numbers during periods of stratification than during upwelling (Fig. 5). The maximum value, $3.9 \times 10^{6}$ cells $1^{-1}$, was observed during the first period of stratification. However, these organisms did not appear to respond to the third period of stratification (24 to $26 \mathrm{Jan}$ ), and numbers remained below $0.5 \times 10^{6}$ cells $1^{-1}$ from 18 Jan through the end of the study.
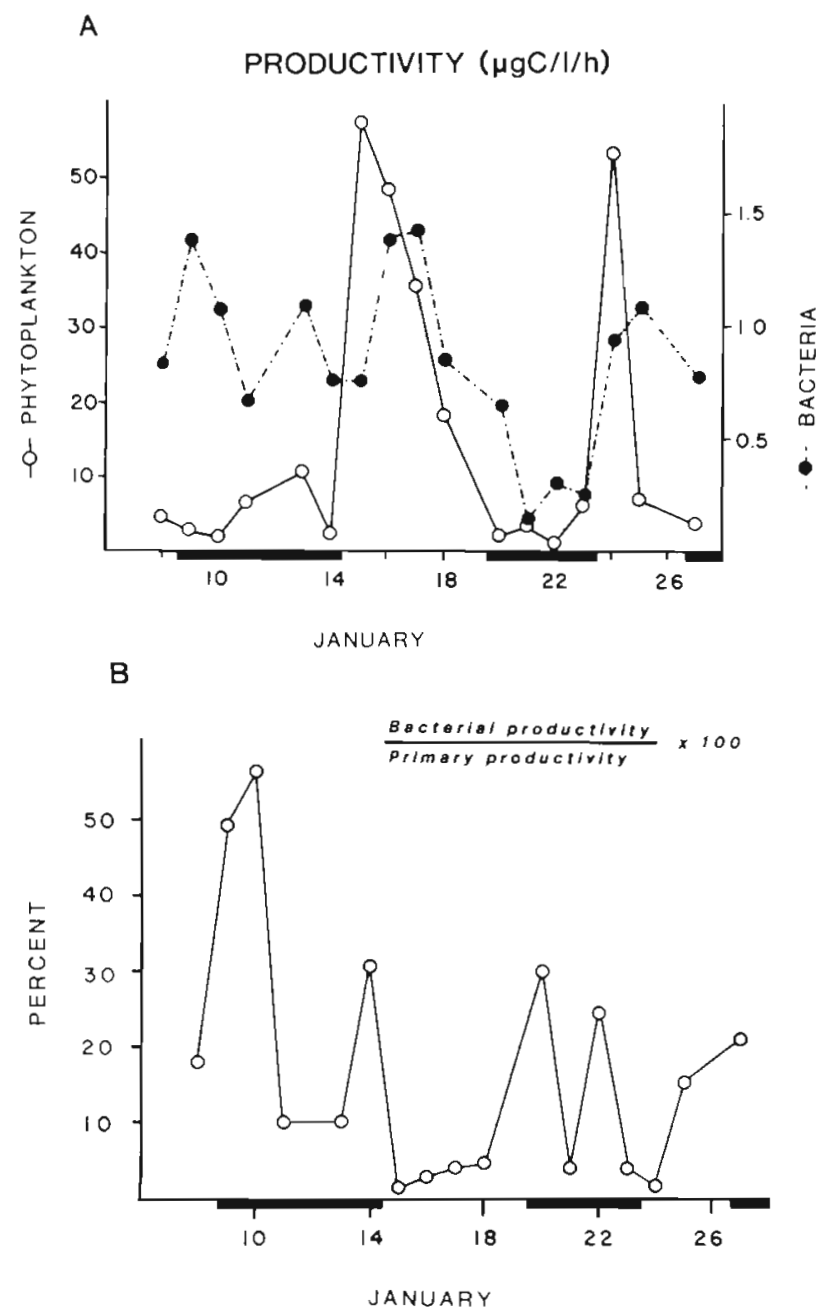

Fig. 4. (A) Phytoplankton and bacterioplankton productivity, and $(B)$ bacterioplankton productivity as a percentage of primary productivity. Black bars on the horizontal axis indicate periods of active upwelling, as in Fig. 3

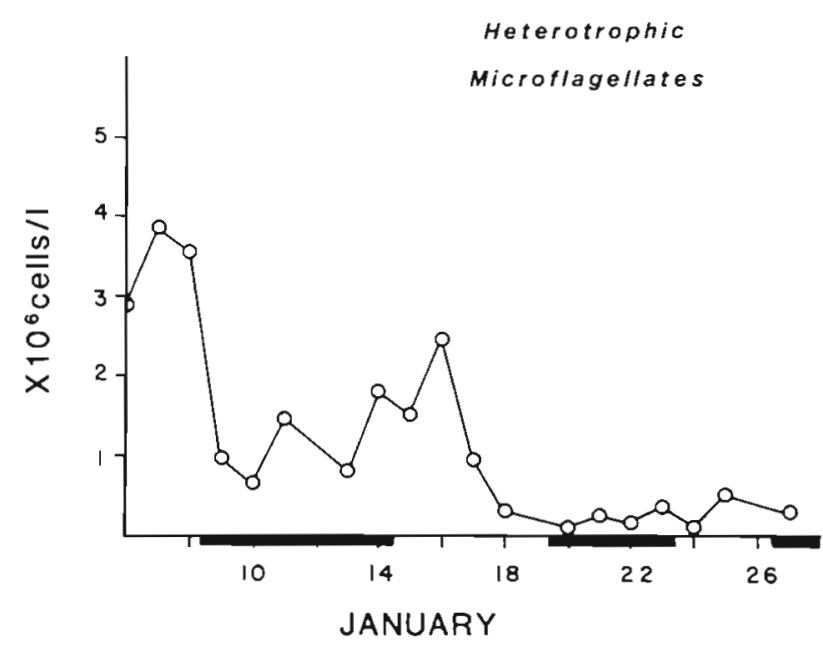

Fig. 5. Abundance of heterotrophic microflagellates (nonpigmented flagellated cells with longest dimensions less than $10 \mu \mathrm{m})$. Black bars on the horizontal axis indicate periods of active upwelling, as in Fig. 3 


\section{DISCUSSION}

Comparisons of phytoplankton and bacterial production are bound to be somewhat inaccurate because of uncertainties in the conversion of thymidine incorporation into cell growth rates (Kirchman et al. 1982, Ducklow \& Hill 1985) and cell numbers into carbon, and in the estimation of bacterial growth efficiency for converting net production (thymidine incorporation) into gross production. Our estimates of bacterial utilization of primary production are conservative, especially considering that photosynthesis was measured at mid-day in surface samples. Since bacterial production continues during the night, bacteria at times may have utilized an amount of carbon in excess of the primary production.

It is also useful to examine the temporal patterns of phytoplankton and bacterioplankton production, especially as they relate to the upwelling cycle. In this study bacterial production was much higher relative to primary production during active upwelling (average $23.9 \%)$ than during stratification $(6.8 \%)$. Sorokin \& Kogelschatz (1979) similarly observed high bacterial activity in newly upwelled water, and Vinogradov \& Shushkina (1978) and Sorokin \& Mikheev (1979) hypothesized that upwelled water passes through heterotrophic and autotrophic phases as it moves offshore and sinks in zones of convergence. Their suggestion was based mainly on the spatial distributions of biological properties in the Peruvian upwelling system. Our temporal data from further south lend some support to it. Although we can say nothing about the fate of the bacteria in the surface water which moved offshore during active upwelling, in the initial stages of the upwelling cycle nearshore water did pass from heterotrophy (bacterial respiration plus production equals or exceeds primary production) to autotrophy. These variations are driven mainly by those of primary production, which varied nearly 50-fold among all our surface measurements. Surface bacterial productivity measurements varied only 10 -fold, from 0.13 to $1.4 \mu \mathrm{g} \mathrm{Cl}^{-1}$ $\mathrm{h}^{-1}$ and except for the 3 lowest values during the second active upwelling event, were within a factor of about 2 .

The observations that bacterial production can be a substantial fraction (or even exceed) primary production and that oscillations in bacterial growth and abundance are damped relative to photosynthesis suggest that bacterioplankton in the nearshore zone are somewhat uncoupled from phytoplankton, especially in newly upwelled water. Although a number of studies have shown strong correlations between bacterial abundance and chlorophyll in coastal environments (Ferguson \& Rublee 1976, Fuhrman et al, 1980) including upwelling regions (Linley et al. 1983) we found only a weak correlation ( $r=0.24 ; n=85$; data not shown) despite strong oscillations in both variables. This correlation was not improved by offsetting the data sets one sampling interval to account for lags. In part this kind of correlation depends on the scale of the observations. Bird \& Kalff (1984) showed that bacterial abundance was strongly correlated with chlorophyll concentration for measurements spanning several orders of magnitude and ranging through marine and freshwater habitats. Ducklow (1984), however, showed that bacteria and chlorophyll were not correlated on a scale comprising the interior of an oceanic warm-core ring but were significantly correlated on larger spatial scales. Ducklow \& Kirchman (1983) observed a similar pattern in the New York Bight, where bacterial abundance was correlated with chlorophyll in waters of higher salinity but not in the fresher waters of the Hudson River outflow plume, where bacterial production was dependent upon external sources of dissolved organic matter. Possibly bacteria in newly upwelled water are utilizing growth substrates generated by herbivory or sinking of senescent phytoplankton in offshore waters and advected inshore at depth during upwelling.

The fate of bacterial production has been a topic of great interest to aquatic microbial ecologists in recent years. High bacterial growth rates in both coastal and open ocean environments are usually not accompanied by commensurate increases in bacterial abundance, so it has generally been inferred that growth and mortality are closely coupled (Ducklow 1983). To examine this relationship, we compared observed abundance of bacteria in surface water with that predicted from the previous day's abundance and growth rate. Fig. 6 shows that the predicted abundance is nearly always higher than that observed. The discrepancy was especially large during active upwelling on 10,11 and 14 Jan, when advection of bacteria away from the station and mixing of surface water with bacteria-poor deeper water occurred. Discrepancies were also observed during some of the dates of stratification suggesting that advection and mixing are not the only factors balancing growth at our station. The accumulation of bacterial biomass in the surface water nearly matched that predicted from growth only during the latter third of the study period. This was a period when heterotrophic microflagellates (major predators on bacteria; Fenchel $1982 \mathrm{a}$, b) remained low in abundance, suggesting that they were an important source of bacterial mortality.

To estimate the grazing impact of heterotrophic microflagellates on bacterioplankton we converted flagellate abundance to biomass using a measured average cell volume of $45 \mu^{3}$, and used a clearance rate of $10^{5}$ body volumes flagellate ${ }^{-1} \mathrm{~h}^{-1}$ (rounded from Fenchel's [1982b] laboratory study: average $8 \times 10^{4}$ for 


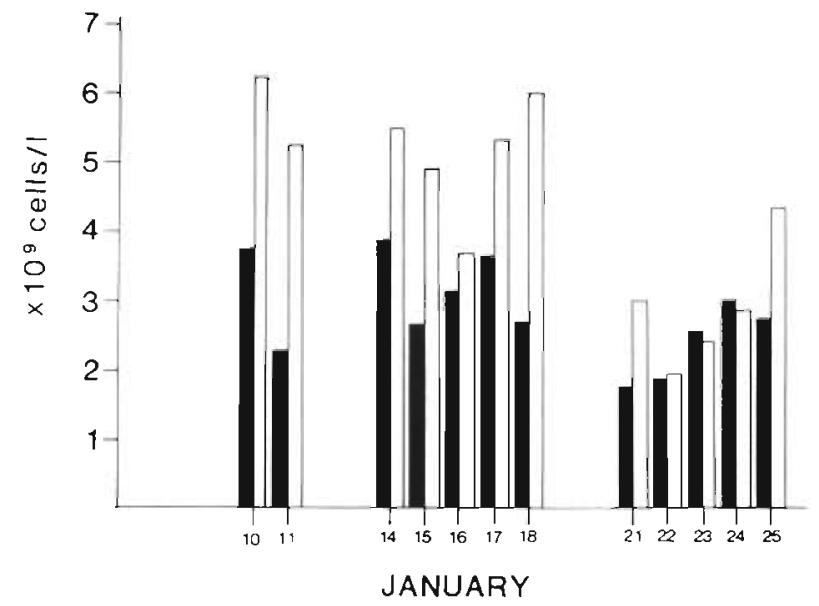

Fig. 6. Observed surface bacterial abundance (black bars) vs that predicted from the previous day's abundance and growth rate (open bars), assuming exponential growth. Gaps occur

because samples were not collected on 12 and $19 \mathrm{Jan}$

5 flagellate species, omitting the value for Actinomonas mirabilis). The results suggest that these organisms were usually not sufficiently abundant to control bacterial populations during either upwelling or stratification. Other protozoa, such as small oligotrichid ciliates, were observed, but not quantified, in the flagellate samples. These bacterivorous organisms probably accounted for some grazing (Rivier et al. 1985, Sherr et al. 1986, Sherr \& Sherr 1987). Bacterivorous pigmented flagellates may also have been responsible for some bacterial mortality (Estep et al. 1986) although in an environment replete with light and nutrients one would expect photosynthesis to provide their main source of energy.

As a fraction of bacterial biomass, flagellate biomass was higher during stratification $(8.6 \%)$ than during upwelling $(3.6 \%)$. It appears that grazing is a more significant source of mortality in the nearshore zone during extended periods of stratification than during shorter ones. Short periods of stratification occurring between strong upwelling events (for example 24 to 26 Jan in the present study) provide insufficient time for bacterivore populations to respond to increased bacterial abundance, resulting in lower bacterial mortality relative to growth. Subsequent active upwelling would then be expected to transport accumulated bacterial production offshore. During longer periods of stratification more of the bacterial production would be mineralized in the nearshore zone

It should also be noted that upwelling-related oscillations in bacterial populations were superimposed on a longer scale overall decline. Bacterial standing stock (cells $\mathrm{m}^{-2}$ ) was negatively correlated with time over the whole course of our study $(r=-0.67 ; p<0.01)$, suggesting that progressively longer bouts of upwellingfavorable winds, with shorter intervening periods of calm (cf. Fig. 1), may flush bacteria out of the nearshore zone on a time scale of at least several weeks. Thus the periodicity of strong and weak upwelling events, in addition to predator-prey interactions within a single upwelling event cycle, may affect the utilization of primary production by bacteria in the nearshore zone.

Although information on bacterioplankton in coastal upwelling ecosystems is scarce, the available data suggest that these systems are not unlike other coastal environments with regard to bacterial abundance and activity. Studies of upwelling off Portugal (Gocke et al. 1983, Rheinheimer \& Schmaljohann 1983), northwest Africa (Zimmermann et al. 1980) and southwest Africa (Field et al. 1980, Linley \& Field 1982) reported bacterial populations on the order of $10^{9}$ cells $l^{-1}$, the great majority of which were not attached to particles. Watson (1978) used indirect methods to estimate that about half of all primary productivity passed through bacteria in coastal upwelling ecosystems. He estimated that more than half ot that activity took place in the sediments. Our results more nearly resemble those of Sorokin \& Kogelschatz (1979) in that we found substantial bacterial utilization of primary production in the water column. More data must be collected using newer methods for estimating abundance and activity of bacterioplankton before we are able to evaluate their role in upwelling food webs.

Our decision to emphasize temporal variations of the plankton in response to the upwelling cycle was rewarded in that we were able to observe 3 complete cycles during our 3 wk study. However, to some extent this was done at the expense of spatial resolution, and the effects of advection and horizontal mixing were not measured. In particular, we are unable to evaluate the extent to which 'seeding' of the newly upwelled water with bacterial populations from offshore surface waters occurred. During stratification, salinity at the surface was generally slightly lower than during upwelling. Given the absence of substantial freshwater runoff in the area, this suggests that lower salinity water from the Humboldt Current mixes with newly upwelled water at the surface in the nearshore zone when southerly winds relax or reverse. Thus bacterial populations at the surface during stratification are probably a mixture of bacteria from deeper waters, possibly surviving on more refractory material, and those from offshore surface waters, adapted to conditions of richer dissolved organic matter from photosynthesis or zooplankton excretion. Studies like the present one are thus complementary to larger scale spatial surveys (e.g. Gocke et al. 1983) and drogue studies (Herbland 1978), which have demonstrated the general increase in bacterioplankton activity with increasing age of upwelled water.

While much more basic data are needed before we 
understand the role of bacterioplankton in coastal upwelling ecosystems, our results suggest a few questions to focus on. For example, do bacterioplankton, whose changes in abundance and activity appear to be damped relative to those of phytoplankton, represent a more stable element in the food web? If so, do changes in the proportion of bacterial to primary production during the upwelling cycle cause the microbial food web to interact in a qualitatively different way with the metazoan food web? And is the uncoupling of bacterial and primary production a feature only of high latitude, intermittent upwelling ecosystems or does it occur in persistent systems as well?

Acknowledgements. We thank D. Bellantoni for the primary productivity measurements, and D. Arcos, G. Villouta and the captain and crew of RV 'Lund' (University of Concepción) for assistance in the field. Drs F. Azam, H. Ducklow, J. Fuhrman, D. Kirchman and Yu. I. Sorokin commented on an earlier version of the manuscript. Financial support was provided by grant INT-8415581 from the National Science foundation, the NSF-funded MECCAS program (GBM; grant to J. Fuhrman) and the Mary Flagler Cary Charitable Trust (GBM).

\section{LITERATURE CITED}

Andrews, P., Williams, P. J. (1971). Heterotrophic utilization of dissolved organic compounds in the sea, III. Measurement of the oxidation rates and concentrations of glucose and amino acids in seawater J. mar. biol. Ass. U. K. 51: $111-125$

Arcos, D. F., Wilson, R. E. (1984). Upwelling and the distribution of chlorophyll-a within the Bay of Concepcion, Chile. Estuar. coast. Shelf Sci. 18: 25-35

Bird, D. F., Kalff, J. (1984). Empirical relationships between bacterial abundance and chlorophyll concentration in fresh and marine waters. Can. J. Fish. Aquat. Sci. 41 $1015-1023$

Ducklow, H. W. (1983). Production and fate of bacteria in the oceans. Bioscience 33: 494-501

Ducklow, H. W (1984). Geographical ecology of marine bacteria: physical and biological variability at the mesoscale. In: Klug, M. J., Reddy, C. A. (eds.) Current perspectives in microbiology. ASM, Washington, p. 22-31

Ducklow, H. W., Hill, S. M. (1985). Tritiated thymidine incorporation and the growth of heterotrophic bacteria in warm core rings. Limnol. Oceanogr 30: 260-273

Ducklow, H. W., Kirchman, D. L. (1983). Bacterial dynamics and distribution during a spring diatom bloom in the Hudson River plume, USA. J. Plankton Res. 5: 333-355

Estep, K. W., Davis, P. W., Keller, M. D., Sieburth, J. McN. (1986). How important are oceanic nanoflagellates in bacterivory? Limnol. Oceanogr. 31: 646-650

Fenchel, T (1982a). Ecology of heterotrophic microflagellates. II. Bioenergetics and growth. Mar. Ecol. Prog. Ser. 8: $225-231$

Fenchel, T (1982b). Ecology of heterotrophic microflagellates. IV Quantitative occurrence and importance as bacterial consumers. Mar Ecol. Prog. Ser. 9: 35-42

Ferguson, R. L., Rublee, P. (1976). Contribution of bacteria to standing crop of coastal plankton. Limnol. Oceanogr. 21: $141-145$
Field, J. G., Griffiths, C. L., Linley, E. A. (1980). Upwelling in a nearshore marine ecosystem and its biological implications. Estuar. coast. mar. Sci. 11. 133-150

Fuhrman, J. A., Ammerman, J. W., Azam, F. (1980). Baterioplankton in the coastal euphotic zone: distribution, activity, and possible relationships with phytoplankton. Mar. Biol. 60: 201-207

Fuhrman, J. A., Azam, F. (1982). Thymidine incorporation as a measure of heterotrophic bacterial production in marine surface waters: evaluation and field results. Mar. Biol. 66: $109-120$

Gocke, K., Hoppe, H.-G., Bauerfeind, T. (1983). Investigations on the influence of coastal upwelling and polluted rivers on the microflora of the northeastern Atlantic off Portugal. II. Activity and biomass production of the bacterial population. Botanica mar. 26: 189-199

Haas, L. W. (1982). Improved epifluorescence microscopy for observing planktonic micro-organisms. Ann. Inst. Oceanogr. 58 (S): 261-266

Hagström, §., Larsson, U., Horstedt, P., Normark, S. (1979). Frequency of dividing cells, a new approach to the determination of bacterial growth rates in aquatic environments. Appl. environ. Microbiol. 37: 805-812

Hanson, R. B., Alvarez-Ossorio, M. T., Cal, R., Campos, M. J., Roman, M., Santiago, G., Varela, M., Yoder, J. A. (1986). Plankton response following a spring upwelling event in the Ria de Arosa, Spain. Mar. Ecol. Prog. Ser. 32: 101-113

Herbland, A. (1978). Heterotrophic activity in the Mauritanian upwelling in March 1973: assimilation and mineralization of amino acids. In: Boje, R., Tomczak, M. (eds.) Upwelling ecosystems. Springer-Verlag, New York, p. 155-166

Hobbie, J. E., Daley, R. J., Jasper, S. (1977). Use of Nuclepore filters for counting bacteria by fluorescence microscopy. Appl. environ. Microbiol. 33: 1225-1228

Kirchman, D. K., Ducklow, H. W., Mitchell, R. (1982). Estimates of bacterial growth from changes in uptake rates and biomass. Appl. environ. Microbiol. 44: 1296-1307

Lee, S., Fuhrman, J. A. (1987). Relationships between biovolume and biomass of naturally-derived marine bacterioplankton. Appl. environ. Microbiol. 53: 1298-1303

Linley, E. A S., Field, J. G. (1982). The nature and significance of bacterial aggregation in a nearshore upwelling region. Estuar. coast. Shelf Sci. 14: 1-11

Linley, E. A. S., Newell, R. C., Lucas, M. I. (1983). Quantitative relationships between phytoplankton, bacteria, and heterotrophic microflagellates in shelf waters. Mar Ecol. Prog. Ser 12: 77-89

Parsons, R. T., Maita, Y., Lalli, C. M. (1984). A manual of chemical and biological methods for seawater analysis. Pergamon, New York

Peterson, W. T., Arcos, D. F., McManus, G. B., Dam, H., Bellantoni, D., Johnson, $T$., Tiselius, P. (in press). The nearshore zone during coastal upwelling: daily variability and coupling between primary and secondary production off central Chile. Prog. Oceanogr.

Pomeroy, L. R., (1974). The ocean's food web, a changing paradigm. Bioscience 24: 499-504

Rheinheimer, G., Schmaljohann, R. (1983). Investigations on the influence of coastal upwelling and polluted rivers on the microflora of the northeastem Atlantic off Portugal. I. Size and composition of the bacterial population. Botanica mar 26: 137-152

Richards, F. A. (1981). Coastal upwellung. A.m. Geophys. Union, Washington, D. C

Rivier, A., Brownlee, D. C., Sheldon, R. W. Rassoulzadegan, F. (1985). Growth of microzooplankton: a comparative study 
of bactivorous zooflagellates and ciliates. Mar. microb Food Webs 1. 51-60

Ryther, J. H. (1969). Photosynthesis and fish production in the sea. Science 166: 72-76

Ryther, J. H., Menzel, D. W., Hulburt, E. M., Lorenzen, C. J., Corwin, N. (1971). The production and utilization of organic matter in the Peru Coastal Current. Investigación pesq. 35: 43-59

Sherr, E. B., Sherr, B. F. (1987). High rates of consumption of bacteria by pelagic ciliates. Nature, Lond. 325: 710-711

Sherr, E. B., Sherr, B. F., Fallon, R. D., Newell, S. Y (1986) Small aloricate ciliates as a major component of the marine heterotrophic nanoplankton. Limnol. Oceanogr. 31: $177-183$

Sieburth, J. McN., Johnson, K. M., Burney, C. M., Lavoie, D. M. (1977). Estimation of in situ rates of heterotrophy using diurnal changes in organic matter and growth rates of picoplankton in diffusion culture. Helgoländer wiss. Meeresunters. 30: 565-574

Smith, W. O., Jr, Barber, R. T., Huntsman, S. A. (1977). Primary production off the coast of northwest Africa: excretion of dissolved organic matter and its heterotrophic uptake. Deep Sea Res. 24: 35-47

Sorokin, Y. I., Kogelschatz, J. E. (1979). Analysis of heterotrophic microplankton in an upwelling area. Hydrobiologia 66: 195-208

Sorokin, Y I., Mikheev, V. N. (1979). On characteristics of the Peruvian upwelling ecosystem. Hydrobiologia 62: 165-189

van Es, F. B., Meyer-Reil, L.-A. (1982). Biomass and metabolic activity of heterotrophic marine bacteria. Adv. microb. Ecol. 6: 111-170

Vinogradov, M. E., Shushkina, E. A. (1978). Some development patterns of plankton communities in the upwelling areas of the Pacific Ocean. Mar. Biol. 48: 357-366

Watson, S. W. (1978). Role of bacteria in an upwelling ecosystem. In: Boje, R., Tomczak, M. (eds.) Upwelling ecosystems. Springer-Verlag, New York, p. 139-154

Zimmermann, R., Bolter, M., Wolter, K. (1980). Eco-bacteriological investigation in the NW African coastal upwelling area. Botanica mar. 23: 179-191

This article was presented by Dr M. Levandowsky; it was accepted for printing on December 23, 1987 